\title{
Particle characterization at the Cape Verde atmospheric observatory during the 2007 RHaMBLe intensive
}

\author{
K. Müller, S. Lehmann, D. van Pinxteren, T. Gnauk, N. Niedermeier, A. Wiedensohler, and H. Herrmann \\ Leibniz-Institut für Troposphärenforschung e.V., Permoserstr. 15, 04318 Leipzig, Germany
}

Received: 9 September 2009 - Published in Atmos. Chem. Phys. Discuss.: 27 October 2009

Revised: 1 March 2010 - Accepted: 9 March 2010 - Published: 23 March 2010

\begin{abstract}
The chemical characterization of filter high volume (HV) and Berner impactor (BI) samples PM during RHaMBLe (Reactive Halogens in the Marine Boundary Layer) 2007 shows that the Cape Verde aerosol particles are mainly composed of sea salt, mineral dust and associated water. Minor components are nss-salts, OC and EC. The influence from the African continent on the aerosol constitution was generally small but air masses which came from south-

their heavily increased concentration in the 1.2 to $3.5 \mu \mathrm{m}$ fraction as compared to their concentration during the nondust periods. For the organic constituents, oxalate (78$151 \mathrm{ng} / \mathrm{m}^{3}$ ) and methanesulfonic acid (MSA, 25-100 $\mathrm{ng} / \mathrm{m}^{3}$ ) are the major compounds identified. A good correlation between nss-sulphate and MSA was found for the majority of days indicating active DMS chemistry and low anthropogenic influences.
\end{abstract} western Europe crossing the Canary Islands transported dust to the sampling site together with other loadings. The mean mass concentration was determined for $\mathrm{PM}_{10}$ to $17 \mu \mathrm{g} / \mathrm{m}^{3}$ from impactor samples and to $24.2 \mu \mathrm{g} / \mathrm{m}^{3}$ from $\mathrm{HV}$ filter samples. Non sea salt (nss) components of PM were found in the submicron fractions and nitrate in the coarse mode fraction. Bromide was found in all samples with much depleted concentrations in the range $1-8 \mathrm{ng} / \mathrm{m}^{3}$ compared to fresh sea salt aerosol indicating intense atmospheric halogen chemistry. Loss of bromide by ozone reaction during long sampling time is supposed and resulted totally in $82 \pm 12 \%$ in coarse mode impactor samples and in filter samples in $88 \pm 6 \%$ bromide deficits. A chloride deficit was determined to $8 \%$ and $1 \%$ for the coarse mode particles $(3.5-10 \mu \mathrm{m} ; 1.2-$ $3.5 \mu \mathrm{m})$ and to $21 \%$ for filter samples.

During 14 May with high mineral dust loads also the maximum of OC $\left(1.71 \mu \mathrm{g} / \mathrm{m}^{3}\right)$ and EC $\left(1.25 \mu \mathrm{g} / \mathrm{m}^{3}\right)$ was measured. The minimum of TC $\left(0.25 \mu \mathrm{g} / \mathrm{m}^{3}\right)$ was detected during the period 25 to 27 May when pure marine air masses arrived. The concentrations of carbonaceous material decrease with increasing particle size from $60 \%$ for the ultra fine particles to $2.5 \%$ in coarse mode PM.

Total iron (dust vs. non-dust: 0.53 vs. $0.06 \mu \mathrm{g} \mathrm{m}^{3}$ ), calcium $\left(0.22\right.$ vs. $\left.0.03 \mu \mathrm{g} \mathrm{m}^{3}\right)$ and potassium $\left(0.33\right.$ vs. $\left.0.02 \mu \mathrm{g} \mathrm{m} \mathrm{m}^{3}\right)$ were found as good indicators for dust periods because of

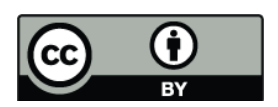

Correspondence to: $\mathrm{H}$. Herrmann (herrmann@tropos.de)

\section{Introduction}

Interactions between the oceanic surface layer, gas phase, atmospheric particles and clouds have a very complex nature and influence atmospheric chemistry and climate (Charlson et al, 1987; Kettle and Andreae, 2000). Atmospheric halogen chemistry is one topic of experimental field and laboratory research in the marine boundary layer as well as modeling (e.g., Duce et al., 1963; Keene et al., 1990; Vogt et al., 1996; von Glasow et al. 2002a, b; Sander et al., 2003) for a long time. A recent study (Read et al., 2008) has shown that reactive halogen species accelerate ozone destruction over the tropical ocean. Interactions between halogen compounds, sulfur species, hydrocarbons and other organic matter from the ocean can contribute to formation of particulate matter. Marine aerosol composition continues to represent a large source of uncertainty in the study of climate and atmospheric chemistry. Chemical processes were induced by the emission of $\mathrm{Cl}^{-}$and $\mathrm{Br}^{-}$species from sea salt. The RHaMBLe (Reactive Halogens in the Marine Boundary Layer) project experiments are focused on experimental research in the northern tropical Atlantic summarized by Lee et al. (2010).

Besides the complex measurements during ship cruises in the region, the construction of the Cape Verde Atmospheric Observatory (CVAO) at the north eastern coastline of the island São Vicente represents a new quality for long term observations in the northern trade winds region of the tropical

Published by Copernicus Publications on behalf of the European Geosciences Union. 
eastern Atlantic. Starting in early 2006, the CVAO was constructed by joint activities of the UK SOLAS program, the European project TENATSO, and the German project SOPRAN in intensive co-operation with the Cape Verdean institute INMG (Instituto Nacional de Meteorologia e Geofísica).

This region of the Atlantic ocean is interesting not only for the gas- and multiphase halogen chemistry but also for the investigation of the aerosol with respect to the interactions between particulate matter (PM) long range transported from the world biggest desert Sahara, the sea spray PM consists not only in sea salt but also in PM of biogenic marine origin.

São Vicente is already far enough from the source region and about $900 \mathrm{~km}$ in the main wind direction off the coast of West Africa (Mauretania and West Sahara). During the transportation of dust, chemical transformations can occur that can lead to a much greater solubility of iron than in the Saharan source regions (Baker and Jickells, 2006). There is an ongoing scientific discussion about iron solubility from emitted and processed mineral dust. In this study only the total iron was characterized in size segregated PM samples. The time of the experiment is known for minimal influences to the aerosol composition from dust transports.

Besides the quasi-continuous filter sampling, during RHaMBLe, in an intensive measurement campaign, the present work focused on the investigation of size-resolved marine particulates in five size fractions with respect to the analysis of mass, concentration of ionic components, organic and elemental carbon (OC; EC), iron, and organic single compounds (MSA and dicarboxylic acids) as well as number concentration and size distribution. Such data sets have been often requested (e.g., Mahowald et al., 2005) but only a few data are actually existing from source regions but not from the main deposition region in the tropical North Atlantic with the exception of the work of Chiapello et al. (1995). These authors collected filter samples over three years for metal analyses at the Cape Verde island Sal. From some ship cruises in this region also short time aerosol particle data exist (e.g., Chen and Siefert, 2004, Rijkenberg et al., 2008).

The current study reports on aerosol particle characterization during the RHaMBLe campaign with the aim to deliver chemical composition data for further use. For future modeling, long term experimental data are needed about the total dust deposition and its size-resolved chemical composition.

\section{Experimental}

\subsection{Site description and sampling}

The Cape Verde Islands are a volcanic archipelago $700 \mathrm{~km}$ off the west coast of Africa. The Cape Verde Atmospheric Observatory (CVAO - Observatório Atmospherico de Cabo Verde: Humberto Duarte Fonseca) was built in 2006 on the north-east coast of the island of São Vicente $\left(16^{\circ} 51^{\prime} 50^{\prime \prime} \mathrm{N}\right.$, $24^{\circ} 52^{\prime} 2^{\prime \prime} \mathrm{W}, 10 \mathrm{~m}$ a.s.l.), $70 \mathrm{~m}$ from the coastline. Prevailing strong north-eastern trade winds heading from the Canary Islands and the North African continent are blowing directly off the ocean. On the coast, influences from the island itself like dispersed dust, orographic influences in dust sedimentation or anthropogenic emissions are very small in the area. The climate on São Vicente is arid with a maximum of $50 \mathrm{~mm}$ rainfall per year. Therefore dominantly dry dust deposition is to be expected. The annual average temperature is about $25^{\circ} \mathrm{C}$. For the aerosol measurements a $30 \mathrm{~m}$ high tower was built to reduce the strong influence of sea spray on the samples (inlet height: $32 \mathrm{~m}$ ).

The particle sampling for RHaMBLe intensive took place between 14 May 2007 and 14 June 2007. Filter and impactor samples have been taken in a 24-h-mode in general. From 25 May to 8 June the mode was changed to 48 -h due to extremely clean air masses and non-detectable amounts of PM in the size-resolved samples.

A high volume Digitel filter sampler DHA-80 (Walter Riemer Messtechnik, Germany) with $\mathrm{PM}_{10}$-inlet was installed on top of the $30 \mathrm{~m}$ high tower. Samples were collected on pre-heated $150 \mathrm{~mm}$ quartz fiber filters (Munktell, MK 360) with an average flow rate of $5001 / \mathrm{min}$. For the size-resolved impactor samples a 5-stage Berner impactor (Hauke, Gmunden, Austria) made of stainless steel was also mounted in $30 \mathrm{~m}$ height. It was operated with a flow rate of $75 \mathrm{l} / \mathrm{min}$. As the substrate material pre-baked aluminum foils were used $\left(350^{\circ} \mathrm{C}\right.$ for two hours). Additional pieces of Nuclepore polycarbonate foils (Wicom, Heppenheim, Germany) for the determination of metals were exposed on each stage (stage 1: $0.05-0.14 \mu \mathrm{m}$, stage 2: $0.14-0.42 \mu \mathrm{m}$, stage 3 : $0.42-1.2 \mu \mathrm{m}$, stage $4: 1.2-3.5 \mu \mathrm{m}$, stage $5: 3.5-10 \mu \mathrm{m}$ ) covering $7-10 \%$ of the stage area. $\mathrm{A} \mathrm{PM}_{10}$ anisokinetic inlet was mounted on the impactor.

After sampling all filters and aluminum foils were stored in aluminum boxes at $5{ }^{\circ} \mathrm{C}$. The Nuclepore-foils were stored in polystyrene boxes. To avoid transport disturbances all samples were transported as hand luggage under ambient conditions to Leipzig. The filters and aluminum foils were equilibrated for 3 days at $20^{\circ} \mathrm{C}$ and $50 \%$ relative humidity. Masses were determined by the use of micro-balances (HVfilter: Mettler AT261 Delta Range, impactor foils: Mettler Toledo UMT2). The Nuclepore polycarbonate foils were not weighed. A correction was made by the number of spots on the Nuclepore polycarbonate foil und the assumption that all spots have identical mass contribution to the total stage mass. For further chemical analysis the filters have been divided into quarters, the aluminum foils were divided by the number of particle spots, differing between size fractions (38-53\% for ion analysis, $25-40 \%$ for OC/EC analysis, and $8-28 \%$ for organic single species analysis, $7-10 \%$ are unloaded while covered by Nuclepore polycarbonate foil). 


\subsection{Analytical methods}

Ion analysis

For ion analysis Digitel filters were extracted with $30 \mathrm{ml}$ MilliQ-water $\left(18 \mathrm{M} \Omega \mathrm{cm}^{-1}, 15\right.$ min shaker, 15 min ultrasonic bath, 15 min shaker), Berner samples with $2 \mathrm{ml} \mathrm{MilliQ-water}$ (10 min shaker, 10 min ultrasonic bath, 10 min shaker). All samples were filtered with $0.45 \mu \mathrm{m}$ pre-cleaned one-way syringe filters to remove insoluble materials. Ion analysis was performed for cations $\mathrm{Na}^{+}, \mathrm{NH}_{4}^{+}, \mathrm{K}^{+}, \mathrm{Mg}^{2+}, \mathrm{Ca}^{2+}$ with ion-chromatography (Waters IC-Pak C M/D Column, eluent: $0.1 \mathrm{mM}$ EDTA, $3.0 \mathrm{mM} \mathrm{HNO}$ ). To determine bromide along the high chloride-concentrations of the sea salt, a special column Metrosep A Supp 5 (Metrohm) was used in a Compact IC 761 (Metrohm LTD, Switzerland) to measure the anions $\mathrm{Cl}^{-}, \mathrm{Br}^{-}, \mathrm{NO}_{3}^{-}, \mathrm{SO}_{4}^{2-}$ and $\mathrm{C}_{2} \mathrm{O}_{4}^{2-}$ (eluent: $1 \mathrm{mM}$ $\mathrm{NaHCO}_{3} / 3.2 \mathrm{mM} \mathrm{Na} \mathrm{CO}_{3}$, flow rate: $0.7 \mathrm{ml} / \mathrm{min}$ ). The detection limits for the ions were determined from blanks and their standard deviation of empty impactor foil measurements according to sampling volume to $0.2 \mathrm{ng} / \mathrm{m}^{3}$ (for $\mathrm{Br}^{-}$ and $\mathrm{C}_{2} \mathrm{O}_{4}^{2-}$ ), via $0.6 \mathrm{ng} / \mathrm{m}^{3}$ for $\mathrm{Na}^{+}, \mathrm{K}^{+}, \mathrm{NH}_{4}^{+}$, and $\mathrm{Mg}^{2+}$ up to $1.2 \mathrm{ng} / \mathrm{m}^{3}$ (for $\mathrm{NO}_{3}^{-}, \mathrm{SO}_{4}^{2-}$,).

Methanesulfonic acid (MSA), succinic acid, and malonic acid were analyzed from the filtrated aqueous extract using capillary electrophoresis (CE) with indirect UV detection. The Spectra Phoresis 1000 (Thermo Separation Products, USA) was equipped with a fused silica capillary $(70 \mathrm{~cm}$ length, $63 \mathrm{~cm}$ to detector, $75 \mu \mathrm{m}$ i.d.). For separation, the capillary was filled with a background electrolyte consisting of $10 \mathrm{mmol}^{-1} \mathrm{p}$-aminobenzoic acid, $8 \mathrm{mmol}^{-1}$ diethylenetriamine, and $3.5 \mathrm{mmol}^{-1}$ aqueous sodium hydroxide $(\mathrm{pH}=9.6)$. After hydrodynamic injection at $10.3 \mathrm{kPa}$ for $30 \mathrm{~s}$, a separation voltage of $30 \mathrm{kV}$ was applied. Indirect detection was performed at $254 \mathrm{~nm}$. The detection limits were determined to $0.2-0.3 \mathrm{ng} / \mathrm{m}^{3}$ for the organic acids in the $24 \mathrm{~h}$ impactor samples.

\section{Metal analysis}

In cold oxygen plasma the polycarbonate-foils were ashed within $1.5 \mathrm{~h}$ on polished quartz wafer substrates. Stage 5 of the impactor has only 15 jets. The problem for the metal analysis is the size of this spot and his visibility on the white substrate. The spot has a diameter of $6 \mathrm{~mm}$ and the irradiated area of the sample in the TXRF has a diameter of $10 \mathrm{~mm}$. To fix the sample at the correct place of the sample holder the sample must be visible. Metal analysis for total $\mathrm{Ca}, \mathrm{Fe}$, $\mathrm{Zn}, \mathrm{Mn}$ and $\mathrm{K}$ was performed with Total Reflection X-Ray Fluorescence Spectrometer (TXRF) S2 Picofox (Bruker AXS, Berlin, Germany) for the size segregated samples of the Berner impactor using a Mo-X-ray source. Gallium was used as an internal standard. Depending on the size fraction, different amounts were applied (10 ng for the three submicrometer fractions and $100 \mathrm{ng}$ for the coarse mode fraction).

\section{OC/EC analysis}

OC/EC was determined for all filter and impactor samples by a two step thermographic method using a carbon analyzer C-mat 5500 (Ströhlein, Germany) published in Herrmann et al. (2006). The estimation of organic matter (OM) was performed following Turpin et al. (2000) using the equation $\mathrm{OM}=2 \cdot \mathrm{OC}$, which is a recommended value for aged aerosols. The OC/EC analytical method is regularly included in round robin tests in Schmid et al. (2001), INTERCOMP2000 (ten Brink et al., 2004), and EUSAAR (not published). The results in the last 2009 EUSAAR experiments have shown that the method used is comparable to the methods with optical corrections (EUSAAR-2, NIOSH, and IMPROVE protocol), while charring processes cannot be fully excluded but have no significant influences on the results at the temperature of $650^{\circ} \mathrm{C}$ used in our method. Optical correction methods need uniform filter samples. Better than optical correction methods are methods avoiding charring (Yang and Yu, 2002). Non-uniform impactor spots cannot analyzed by a technique using reflection or transmission of light to correct possible charring effects. Charring processes occur at high temperatures but our method is working up to $650^{\circ} \mathrm{C}$ where a weak underestimation of total carbon is the only possibility for errors. The detection limits were determined to $10 \mathrm{ng} / \mathrm{m}^{3} \mathrm{EC}$ and $20 \mathrm{ng} / \mathrm{m}^{3} \mathrm{OC}$ for impactor foils and to $30 \mathrm{resp} .100 \mathrm{ng} / \mathrm{m}^{3}$ for EC and OC in filter samples because their higher blank levels.

\section{Physical PM characterization}

To obtain the particle number size distribution in the range of 0.01 to $10 \mu \mathrm{m}$, a SMPS (Scanning Mobility Particle Sizer) in combination with an APS (Aerodynamic Particle Sizer, TSI 3321, TSI Inc., St. Paul Minnesota, USA) were used. The SMPS consists of a DMA (Differential Mobility Analyzer, type Hauke medium) with a selected particle size range of 0.01 to $0.9 \mu \mathrm{m}$ in combination with a CPC (Condensation Particle Counter, TSI 3010, TSI Inc., St. Paul Minnesota, USA). The fundamentals of the SMPS technique are explained in Birmili et al. (1999), who described the instruments and working routine of a T-DMPS (Twin-Differential Mobility Particle Sizer). There are some differences between the SMPS and T-DMPS. The SMPS has a closed loop system, in which the DMA sheath air is re-circulated. The relative humidity for the closed loop varies between 20 and $40 \%$. To get a better time resolution, the voltage setting in the DMA is not stepping (T-DMPS) but scanning (SMPS). With the APS, particle number size distributions in the size range between 0.6 and $10 \mu \mathrm{m}$ (aerodynamic diameter) are obtained. To combine the particle number size distributions of the SMPS and the APS, the aerodynamic particle diameters 
of the APS were converted to volume equivalent diameters (DeCarlo et al., 2004) which is the same diameter as used for the SMPS. The used overlap diameters $(0.7-0.9 \mu \mathrm{m})$ between the SMPS and the APS distributions were averaged to combine both distributions. The inlet of the measurement system was installed only $4 \mathrm{~m}$ above ground on the top of the measurement container.

\section{Results and discussion}

\subsection{Back trajectory investigation}

For the interpretation of the size-fractionated PM constitution, the history of the air mass is more important than the local meteorological conditions because the high atmospheric life time of submicron particles. Using the NOAA HYSPLIT (HYbrid Single-Particle Lagrangian Integrated Trajectory, http://www.arl.noaa.gov/ready/hysplit4.html) model the back trajectories were calculated for each day (starting $500 \mathrm{~m}$ above ground). In Fig. 1a back trajectories ( $72 \mathrm{~h}$ ) between 8 and 13 May are summarized to show the air mass origin over north-western Africa. As can be seen from this figure, before the campaign started (14 May), a major Saharan dust event (daily mean dust concentration on 10/11 May: $332 \mu \mathrm{g} / \mathrm{m}^{3}$ ) took place over São Vicente. Figure 1b summarizes the back trajectories $(72 \mathrm{~h})$ during the intensive measurement period (14 May to 14 June, Julian days 133 to 164). From the back trajectories and the mass determination analysis, only two major classes of samples may be distinguished: (i) continental (dust and anthropogenic emissions) and (ii) only marine aerosol. Only during the beginning of measurements (14 and 15 May), an influence of the African continent was observed by wearing off the Saharan dust event between 8 and 13 May (Fig. 1a). In some of these samples influences of the Iberian peninsula and North Africa should remain. Weak dust influences were determined in non-dust days, too. The back trajectories shown in Fig. 1 represent only the last $72 \mathrm{~h}$ but particles in this size class can have atmospheric lifetimes up to 10 days. Lee et al. (2010) have shown 8 day back trajectories with air mass contacts to the European, African or North-American continent. Slightly higher concentrations of minerals were found between 18-21 May and 26-29 May. All other air masses have their origin in the Atlantic, North and Northwest of Cape Verde (Fig. 1b).

\subsection{PM characterization}

Mass concentration of PM was investigated using three different methods, i.e. impactors, HV-filter sampler and SMPS-APS method. Impactor sampling allows mass determination and chemical characterization of the five size fractions. Filter sampling delivers a high total mass for the chemical analyses and the SMPS-APS measurements provide number concentration in 100 size channels with a high time resolution. It has to be noted that a direct
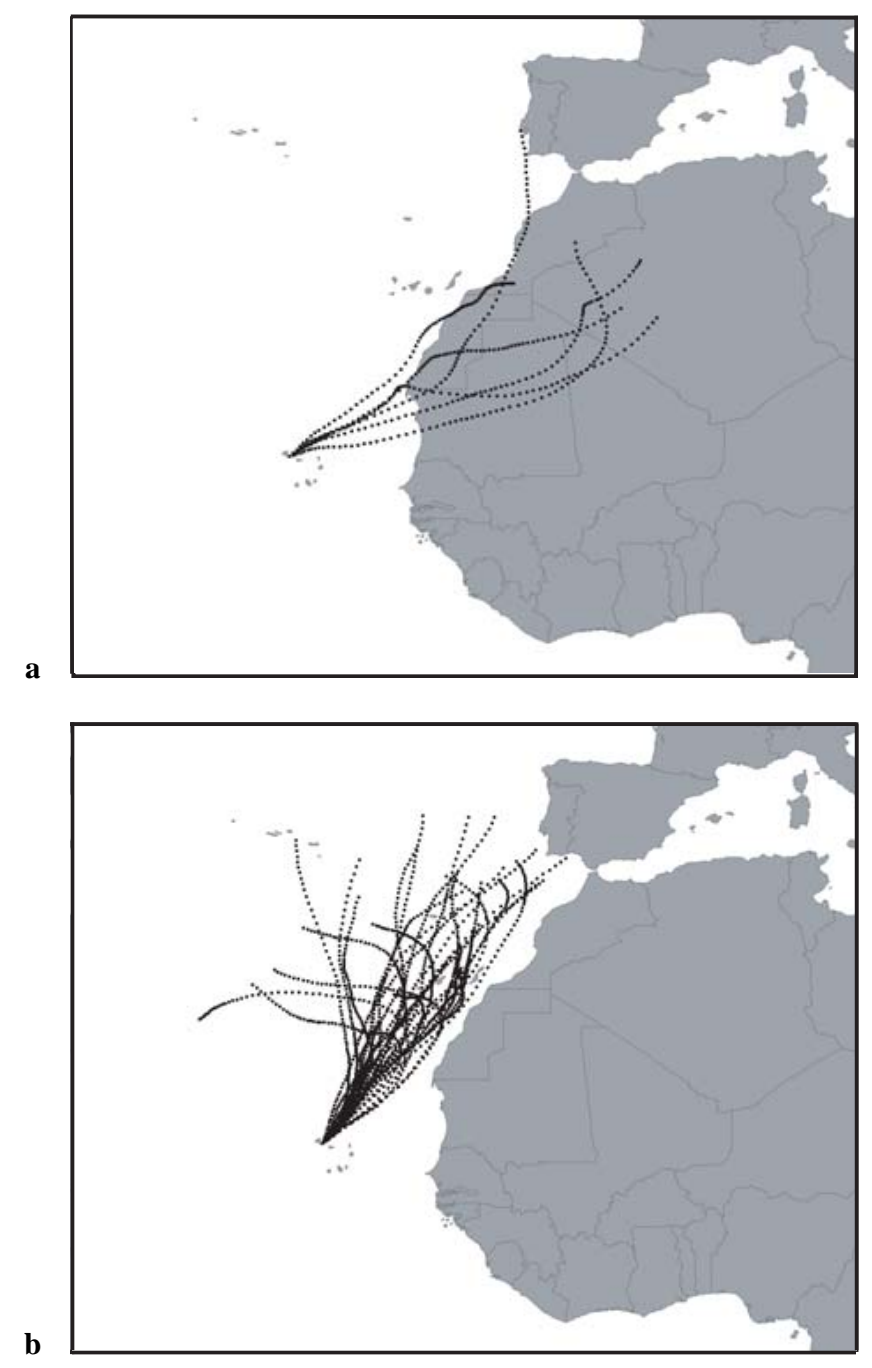

Fig. 1. 72-h back trajectories for the time between 8 and 13 May (a, left) and 14 May and 14 June (b, right) starting each at 00:00 UTC in a height of $500 \mathrm{~m}$ above ground.

comparison for the measurements described here between the offline sampling methods and the physical SMPS-APS measurements is not possible as the inlets of the samplers deployed were not operated at the same height level of the measurement tower, cf. Sect. 2.2. and Fig. 8.

\section{Impactor measurements}

For the impactor sampling, 23 samples in five size fractions each (15 daily and 8 two-day samples) were analyzed. Deduced from the total PM concentration, only two samples showed major mineral dust influence, i.e., summed up to $\mathrm{PM}_{10}$ : $14-15$ May: $69.0 \mu \mathrm{g} / \mathrm{m}^{3}$ and $15-16$ May: $39.4 \mu \mathrm{g} / \mathrm{m}^{3}$ because of their high mass concentration. All other samples were predominantly of maritime origin with some weak continental influences. Mass concentrations of the single stages 


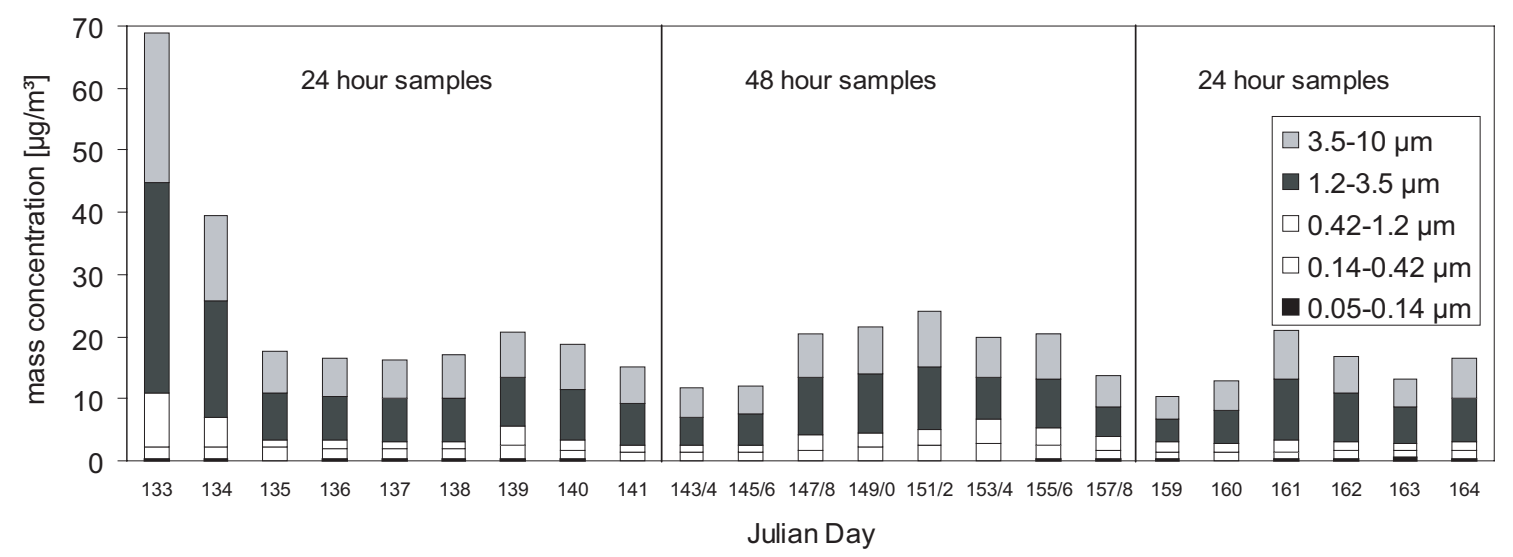

Fig. 2. Mass concentration determined by impactor measurements throughout RHaMBLe intensive.

summed up to $\mathrm{PM}_{10}$ are presented in Fig. 2. Mass concentration varied between 12 and $24 \mu \mathrm{g} / \mathrm{m}^{3}$ with a mean of $17 \mu \mathrm{g} / \mathrm{m}^{3}$ for these mainly maritime aerosols.

In Fig. 3, the mean size distributions of the detected PM constituents are shown for the days influenced by mineral dust (a) and (b) for the maritime days. The water content of PM is not considered. The estimation of the mineral dust content is made only from the iron content according to the mean of $4 \%$ in Saharan dust. For Saharan dust iron contents values between 2 and $8 \%$ are available from literature. In the most recent publications Lafon et al. (2004) reported from Niger-Harmattan $6.3 \% \mathrm{Fe}$, Guieu et al. (2002) found $4.45 \%$ (2.8-5.7\%), Bonnet and Guieu (2004) reported 4.5\%, Schroth et al. (2009) 4.2\%, Moreno et al. (2006) reported values between 1.96 and $4.7 \%$ from different regions in the Sahara. In a modelling study by Hand et al. (2004) 3.5\% for Fe were applied. For estimations $4 \%$ seems to be a suitable value.

In the three size classes below PM diameter $1.2 \mu \mathrm{m}$, elevated mass concentrations were observed resulting from secondary aerosol formation from marine and anthropogenic sources and remaining mineral dust during a number of days (18-21 and 26-29 May). All these air masses came across SW Europe and the Canary Islands. The detailed distribution is shown in Fig. 4 for important PM constituents between particle size fractions.

\section{BI stage $1(\mathrm{Dp}=0.05-0.14 \mu \mathrm{m})$ and BI stage 2 \\ $(D p=0.14-0.42 \mu m)$}

In contrast to the constitution of continental aerosol an extremely low concentration of ultra fine particles $(0.05-0.14 \mu \mathrm{m})$ was found in all samples. In the smallest size fractions mass concentrations were observed to $0.2 \pm 0.1 \mu \mathrm{g} / \mathrm{m}^{3}$ for $0.05-0.14 \mu \mathrm{m}$ and to $1.7 \pm 0.4 \mu \mathrm{g} / \mathrm{m}^{3}$ in the $0.14-0.42 \mu \mathrm{m}$ fraction and consisted mostly of $\mathrm{OM}$, EC, and nss-components. Low concentrations of elemental
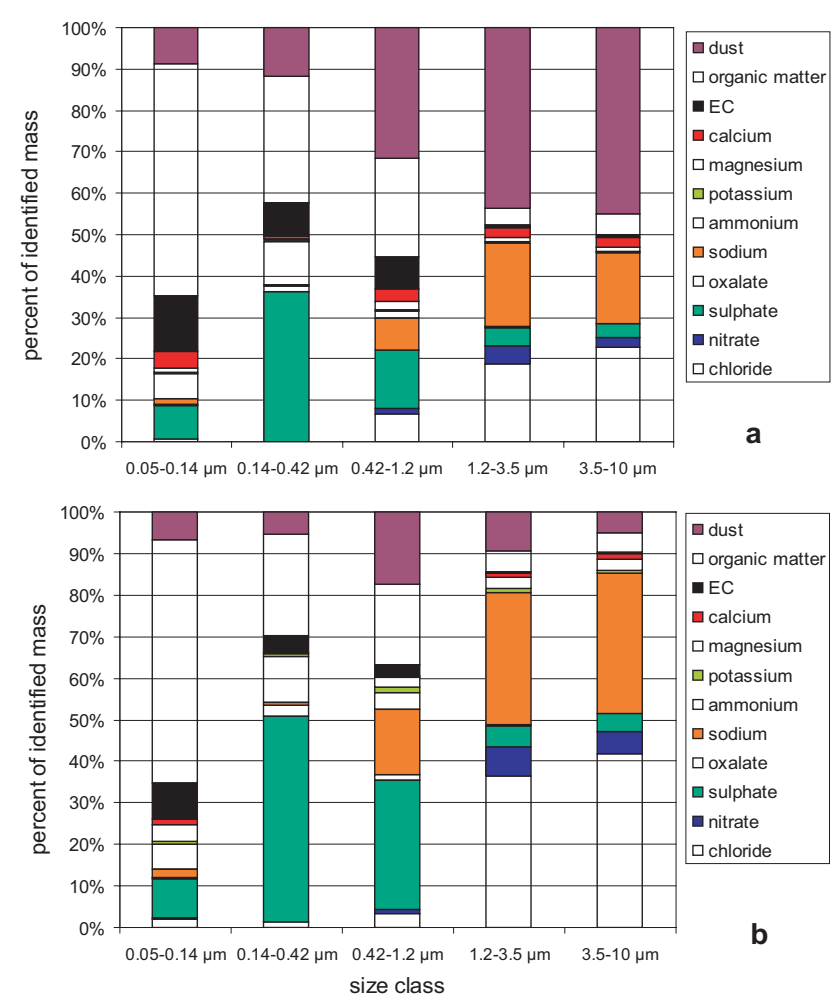

Fig. 3. Identified PM constituents in impactor sample size fractions. ((a) - mean of the two samples collected during dust event, (b) mean of the marine influenced period)

carbon from this PM long range transported were observed after the dust event. However, the concentration of OC found to $60 \pm 33 \mathrm{ng} / \mathrm{m}^{3}$ and of EC to $12 \pm 10 \mathrm{ng} / \mathrm{m}^{3}$ for stage 1 particles. In stage 2 particles which have longest atmospheric life time, OC was found to $88 \pm 65 \mathrm{ng} / \mathrm{m}^{3}$ and EC to $28 \pm 39 \mathrm{ng} / \mathrm{m}^{3}$. Ammonium and nss-sulphate are the major ions. Sea salt was found in extreme low concentrations in these two size classes. Thus, the high calculated 

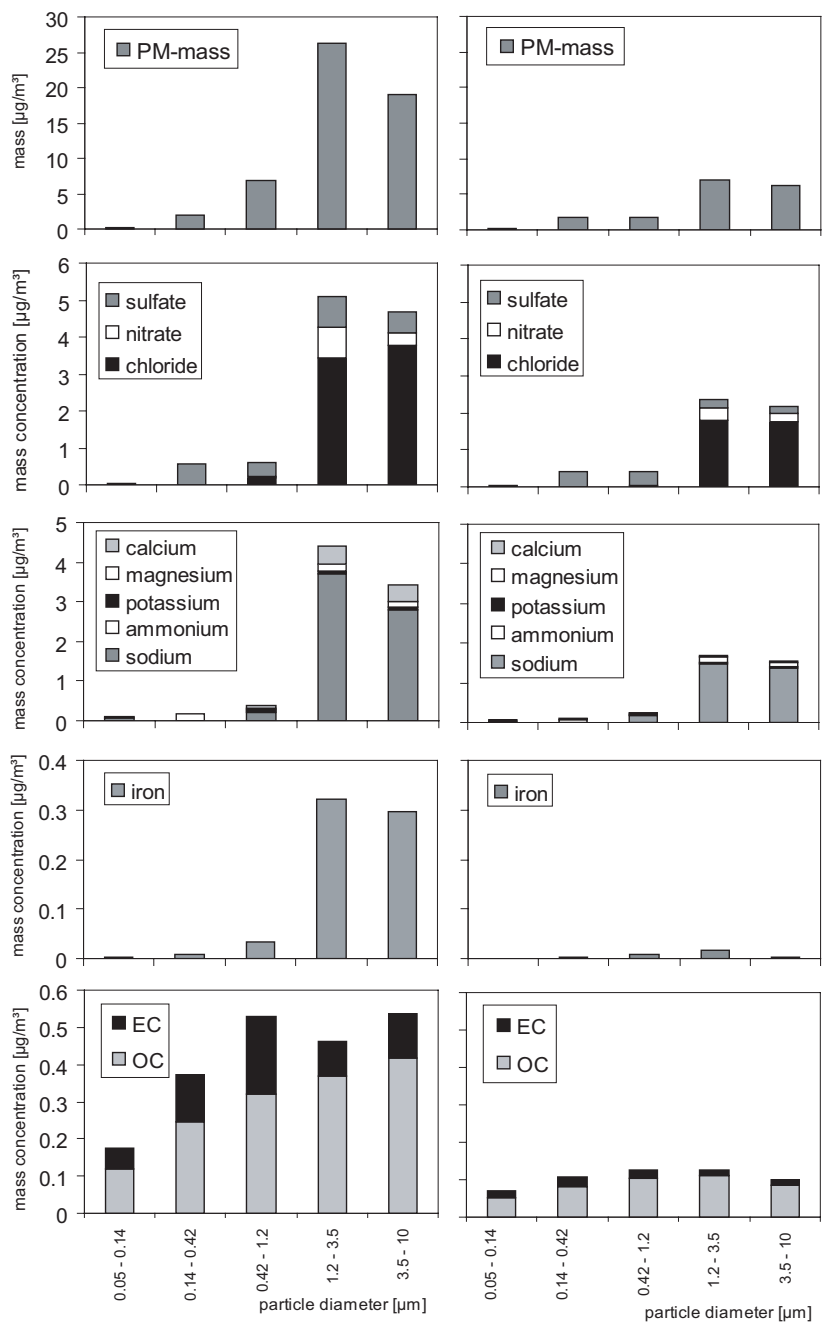

Fig. 4. Detailed size distribution of mass and PM constituents during the dust event (left) and during the low dust marine aerosol (mean values).

chloride deficit of 94 and $79 \%$ is not unexpected and in good agreement with size-resolved measurements by Keene et al. (2004). Less dominant other anions in these fractions are nitrate, oxalate, and methanesulfonate. Sodium, potassium, magnesium, calcium, and chloride were found as minor cations but often below detection limit. Considering the ion balance and the liquid water content of atmospheric PM, a mean $\mathrm{pH}$-value of 0.5 was calculated for the $0.14-0.42 \mu \mathrm{m}$ fraction particles which is in good agreement with the estimation of Herrmann (2003) and measurements of Keene et al. (2002).

\section{BI stage $3(D p=0.42-1.2 \mu m)$}

In comparison to continental aerosols, where the most abundant PM-fraction is observed between $0.42-1.2 \mu \mathrm{m}$, the mass-dominating PM-fractions at the CVAO were observed between $1.2-10 \mu \mathrm{m}$. In the $0.42-1.2 \mu \mathrm{m}$ fraction, externally mixed sea salt, mineral dust and long range transported secondary PM were found, leading to the differences in the observed pattern in comparison to typical continental aerosols. Dust day samples and non-dust day samples are not distinguishably in this fraction by mass, only by minor constituents, e.g. trace metals iron and calcium. The chloride deficit is found to $90 \pm 10 \%$ in this size range, possibly overestimated in some samples from nss-magnesium from continental dust sources.

Due to the similarities in the size distribution between sea salt and Saharan dust with their maximum in the super-micron range differences in mass between dust and marine influenced aerosol could not be observed. However, the concentration of calcium, potassium and iron (Table 1) were used as an indication for dust influence.

\section{BI stage $4(D p=1.2-3.5 \mu m)$ and BI stage 5 $(\mathrm{Dp}=3.5-10 \mu \mathrm{m})$}

The PM concentration maximum was detected in the size fraction $1.2-3.5 \mu \mathrm{m}\left(7.1 \pm 1.7 \mu \mathrm{g} / \mathrm{m}^{3}\right)$ followed by the coarse mode fraction $3.5-10 \mu \mathrm{m}\left(6.3 \pm 1.3 \mu \mathrm{g} / \mathrm{m}^{3}\right)$ for the days after the dust event. OC and EC in coarse mode PM samples were often below the detection limit, especially during the clean marine days. The super-micron fractions were dominated by sodium, chloride, calcium, potassium and magnesium from sea salt but during dust days calcium and potassium were found in higher fraction than in sea salt and mineral dust is the main constituent. The high concentration of nitrate in coarse mode particles originates from the reaction of gaseous nitric acid with sea salt sodium chloride. A chloride deficit of $1 \%$ for the fraction $3.5-10 \mu \mathrm{m}$ and $8 \%$ for the fraction 1.2 $3.5 \mu \mathrm{m}$ was detected. These effects of $\mathrm{HNO}_{3}$ and $\mathrm{H}_{2} \mathrm{SO}_{4}$ in slightly polluted air masses on the particle composition at the Cape Verdes during RHaMBLe are being discussed by Lawler et al. (2009) in line with the findings of the present study.

As a minor component bromide was detected with the maximum concentration typically found at BI stage 4 . The observed bromide deficit calculated versus the conservative element magnesium at both coarse mode fractions of $82 \pm 12 \%$ is very high and in line with a very active photochemical halogen activation chemistry leading to considerable amounts of $\mathrm{BrO}$ in the gas phase as being identified for the first time in a tropical region by Read et al. (2008). Similar high deficits were reported by Ayers et al. (1999) from Cape Grim summer measurements, by Gabriel et al. (2002) from the Indian Ocean and by Keene et al. (2009) from the tropical North Atlantic. Some results for tropical ocean sites (from Sander et al., 2003) were summarized and compared to this study in Table 2 . The reported deficits are mostly smaller but not far from this study results.

The findings of the size distribution and mean concentrations in the samples influenced by dust compared to the 
Table 1. Content of calcium, potassium and iron in impactor samples for two main groups (high dust - low dust) of samples. The percentage in brackets refers to the impactor stage mass.

\begin{tabular}{lllll}
\hline & size fraction & $\mathrm{Ca} \mu \mathrm{g} / \mathrm{m}^{3}(\%)$ & $\mathrm{K} \mu \mathrm{g} / \mathrm{m}^{3}(\%)$ & $\mathrm{Fe} \mu \mathrm{g} / \mathrm{m}^{3}(\%)$ \\
\hline High dust & $0.05-0.14$ & $0.004(1.54)$ & $0.001(0.31)$ & $0.002(0.66)$ \\
& $0.14-0.42$ & $0.006(0.30)$ & $0.010(0.51)$ & $0.008(0.39)$ \\
& $0.42-1.2$ & $0.080(1.18)$ & $0.025(0.37)$ & $0.035(0.51)$ \\
& $1.2-3.5$ & $0.527(2.01)$ & $0.216(0.82)$ & $0.331(1.26)$ \\
& $3.5-10$ & $0.388(2.05)$ & $0.225(1.19)$ & $0.305(1.61)$ \\
Low dust & $0.05-0.14$ & $0.001(0.67)$ & $0.000(0)$ & $0.001(0.32)$ \\
& $0.14-0.42$ & $0.002(0.12)$ & $0.003(0.19)$ & $0.002(0.10)$ \\
& $0.42-1.2$ & $0.017(1.04)$ & $0.013(0.80)$ & $0.008(0.50)$ \\
& $1.2-3.5$ & $0.056(0.82)$ & $0.031(0.44)$ & $0.017(0.24)$ \\
& $3.5-10$ & $0.002(0.04)$ & $0.001(0.02)$ & $0.002(0.04)$ \\
\hline
\end{tabular}

Table 2. Selected intervals of Br depletion in supermicron PM samples in tropical and subtropical non-polluted regions from this study, Keene et al. (2009), and after Sander et al. (2003).

\begin{tabular}{lll}
\hline Campaign & Bromide enrichment factor (range) & Bromide enrichment factor (median) \\
\hline This study filter $\left(\mathrm{PM}_{10}\right)$ & $0-0.33$ & 0.12 \\
This study, impactor $(1.2-10 \mu \mathrm{m})$ & $0.05-0.64$ & 0.17 \\
CGR94, Cape Grim & $0.28($ summer $)-0.95$ (winter) & 0.51 \\
At194 and ATL96b, Atlantic Ocean & $0.07-0.99$ & 0.2 (coarse PM) \\
BEM97, Bermudas & $0.025-0.722$ & 0.19 \\
HAW99; Hawaii & $0.0-0.4$ night & 0.2 \\
SAM81, Samoa & $0.16-0.44$ day & 0.36 \\
Keene et al., 2009, tropical North Atlantic ocean & $0.18-0.81$ & 0.44 \\
\hline
\end{tabular}

marine samples are summarized in Fig. 4 for selected PM constituents.

\section{Organic particle phase constituents}

For organic single species, only oxalate, malonate, succinate and MSA were detected. A few measurements found sugars (glucose, arabitol and mannitol) in concentrations below $3.4 \mathrm{ng} / \mathrm{m}^{3}$. Median concentrations of dicarboxylic acids and MSA are presented in Table 3. For MSA the median concentration was determined to $30 \mathrm{ng} / \mathrm{m}^{3}$. During the dust event the maximum was measured to $67 \mathrm{ng} / \mathrm{m}^{3}$. The distribution of MSA between size fractions yield a maximum in the $0.42-1.2$ and $1.2-3.5 \mu \mathrm{m}$ size classes. These findings and the size distribution are in good agreement with data from Johansen et al. (2000) from a ship cruise near Cape Verde. Further observations about size distribution of dicarboxylic acids in marine aerosols were reported by Baboukas et al. (2000), and Neusüß et al. (2002). Mochida et al. (2003) reported a typical bimodal distribution. In remote areas the oxalate maximum was found in submicron PM where the supermicron particles contain similar or higher amounts of malonate and succinate. Impactor measurements by Hsieh et al. (2007, 2009) from a suburban region in Taiwan were not comparable but in both papers similar observations were reported for non-polluted marine influenced air masses. The discussion of malonate and succinate was coupled to sea spray for observed high concentrations in the supermicron modes. No clear indications are given for this observation and the authors do not speculate about origin or processes of formation. Organic tracers of anthropogenic origin, e.g. PAH, were not found in this study. Surprisingly, in Cape Verde aerosol particles a number of organic amines has been identified. These findings are being discussed separately by Müller et al. (2009).

\section{Metals}

The particle total metal content was only analyzed from Berner impactor samples using TXRF. Total calcium, potassium and iron concentrations and their ratios to the total stage mass collected are summarized in Table 1. From all samples, the size fractions below $3.5 \mu \mathrm{m}$ were analyzed. The PM on Nuclepore polycarbonate foils of stage $5(3.5-10 \mu \mathrm{m})$ were 
Table 3. Median of dicarboxylic acid concentrations and MSA detected in impactor samples during the whole campaign by capillary electrophoresis.

\begin{tabular}{cccccc}
\hline & size fraction $\mu \mathrm{m}$ & oxalate $\mathrm{ng} / \mathrm{m}^{3}$ & malonate $\mathrm{ng} / \mathrm{m}^{3}$ & succinate $\mathrm{ng} / \mathrm{m}^{3}$ & $\mathrm{MSA} \mathrm{ng} / \mathrm{m}^{3}$ \\
\hline Organic acids & $0.05-0.14$ & 1.0 & $0.3^{*}$ & 0.8 & $1.4^{* *}$ \\
& $0.14-0.42$ & 17.1 & 1.3 & 1.0 & 4.9 \\
& $0.42-1.2$ & 6.8 & 1.3 & 1.6 & 11.4 \\
& $1.2-3.5$ & 10.2 & 4.2 & 3.8 & 9.9 \\
& $3.5-10$ & 1.8 & 1.9 & 3.7 & 1.9 \\
\hline
\end{tabular}

* Only in five samples in this size class malonate was found above DL.

** Only in six samples in this size class MSA was found above DL.

not visible at all samples, rendering the analysis for higher dust concentrations impossible because the TXRF needs a piece of sample smaller than $8 \mathrm{~mm}$ in diameter with a distinct PM deposition spot. Hence, a total of 13 samples of BI stage 5 could not be analyzed (sea salt dominated days without dust). A direct comparison between high and low dust concentrations in the fraction between 3.5 and $10 \mu \mathrm{m}$ is hardly possible because the lack of data from several low dust days. Stage 3 and $4(0.42-1.2-3.5 \mu \mathrm{m})$ are the most interesting fractions for the mineral dust determination, given that the highest total mass concentration was also found on stage 4 . The high concentrations of $\mathrm{Fe}, \mathrm{Ca}$ and $\mathrm{K}$ during the dust event compared to their concentrations during low dust days confirm their role as mineral dust indicators.

Calcium concentrations increased during high dust days (9 times higher than during low dust) due to mineral fractions of the source areas. Moreno et al. (2006) reported calcite as an important mineral in the Western Sahara. There is good agreement for the calcium concentrations measured by IC for the water soluble part and by TXRF for total calcium $\left(r^{2}=0.99\right)$. Only $6 \%$ of calcium is found in non-soluble material (Fig. 5).

During 14 and 15 May, air masses had no more direct contact to the African continent but were still loaded with remaining Saharan dust from the event before. Two short periods with weak continental influences were observed between 18 and 21 May and between 27 and 29 May, additionally.

The total iron concentration in the high dust sample during RHaMBLe intensive was 1.7 wt.\%. Our findings with respect to the sea salt, organic matter and water content of the collected PM are in good agreement with the values of Schroth et al. (2009). For the estimation of mineral dust in our samples (compare Fig. 3) the iron concentration (4\% of dust) was used as the basis.

\section{Chemical mass closure for the impactor measurements}

An aerosol mass closure for PM deposited on the impactor stages is possible by the estimation of total mineral dust and the water content. The water content was determined

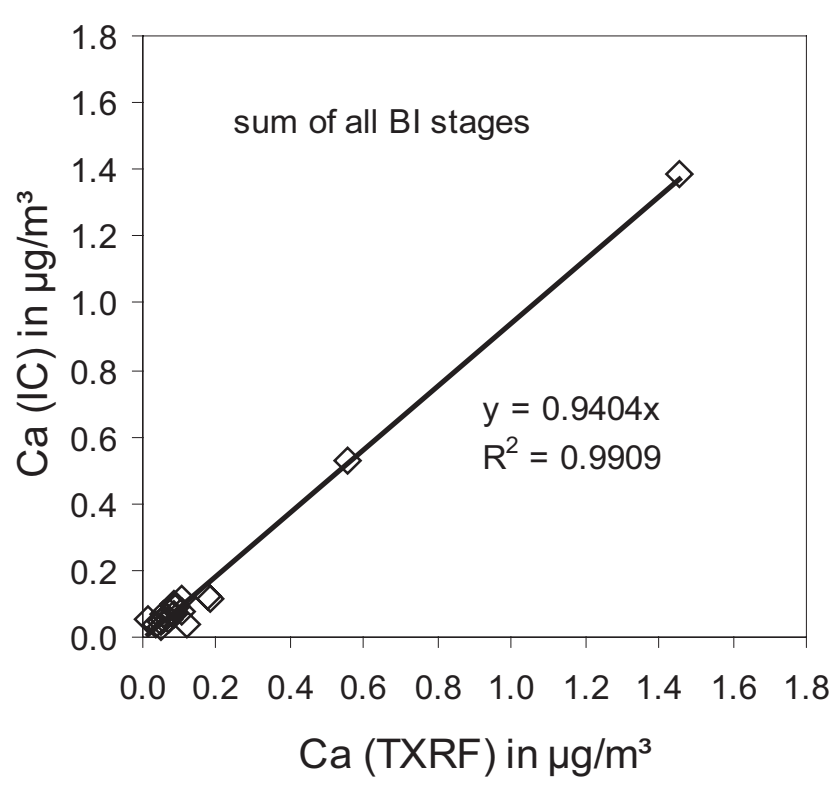

Fig. 5. Correlation of calcium content in impactor samples measured by IC and TXRF.

by the ionic constitution after Neusüß et al. (2000) and the r.H. of $50 \pm 2 \%$ at weighing. In the different size fractions the amount of water was found between $5 \%$ for the nanoparticles to $47 \%$ in the marine coarse mode PM. Taking into account the estimation for water and dust for the sum of the impactor stages gives a total recovery of $95 \pm 10 \%$ for the mass closure. However, in the nano-particle stage a higher error was determined due to analytical and weighing uncertainties to a value of $98 \pm 51 \%$. The water soluble ions, mainly sea salt, contribute to $56 \pm 9 \%$ to the total mass during non-dusty times. In the two dusty samples the ionic contribution was only 31 , resp. $44 \%$. The sum of OM and EC contribute to the total $\mathrm{PM}_{10}$ mass between 1.6 and $9 \%$. During non-dusty days, the contribution of mineral dust was estimated to 0.7 to $7.9 \%$ to the total mass collected, in dusty samples to $30 \%$. 


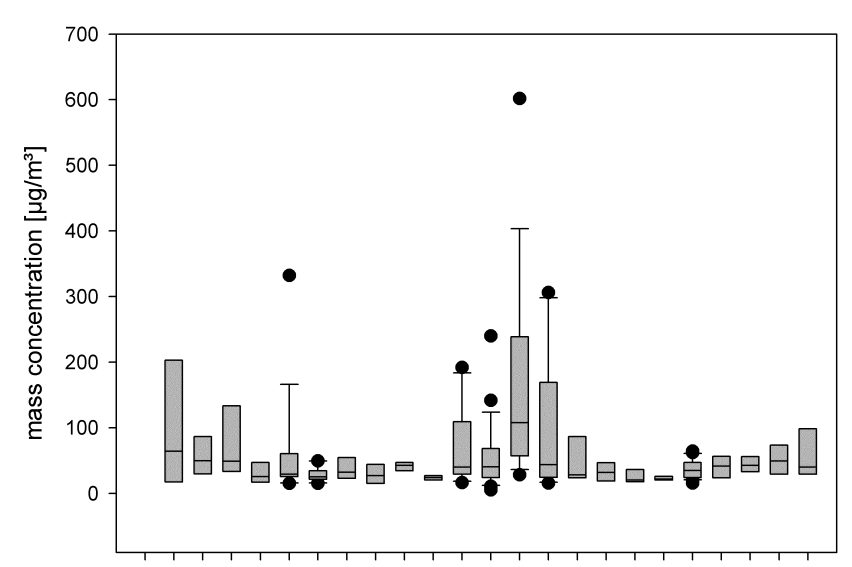

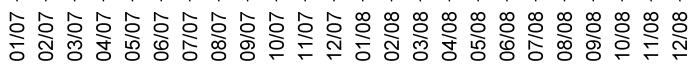

Fig. 6. Box-whisker plot of the monthly measurements of PM mass concentration at the CVAO. Only during intensive campaign the number of monthly measurements is great enough for correct boxwhisker presentation.

Compared to the monthly mean concentrations of 2007 , May and June occur as expected as low-dust summer months, where most of the dust from African continent is transported in higher atmospheric layers above Cape Verde Islands (Prospero and Carlson, 1981, Chiapello et al., 1995, Schepanski et al., 2009). The dust contribution to the total aerosol during RHaMBLe intensive is in good agreement with the monthly mean of $4 \mu \mathrm{g} / \mathrm{m}^{3}$ for May and June reported for the years 1992-1994 by Chiapello et al. (1995) for the island Sal.

\section{Filter measurements}

More than $90 \mu \mathrm{g} / \mathrm{m}^{3}$ of $\mathrm{PM}_{10}$ were observed only during strong dust events. 31 samples were detected during the first two years of continuous measurements, 22 in winter, four in spring and fall each, and one in summer. In May 2007, an exceptional high dust event was observed at São Vicente $\left(\mathrm{PM}_{10}\right.$ mass concentration during 10 to 11 May: $332 \mu \mathrm{g} / \mathrm{m}^{3}$ ) but this peak of dust was wearing with the start of the intensive measurements. With the exception of the first two samples $\left(92\right.$ and $50 \mu \mathrm{g} / \mathrm{m}^{3}$ ), the detected mass concentration of $\mathrm{PM}_{10}$ particles was low $\left(15-31 \mu \mathrm{g} / \mathrm{m}^{3}\right)$ during RHaMBLe campaign and mainly affected by different types of marine aerosol sometimes influenced from natural and anthropogenic emissions in North Africa and the Iberian peninsula. For comparison Fig. 6 shows the monthly mean $\mathrm{PM}_{10}$ concentration and the monthly maximum of our filter sampling data. The observations of Chiapello et al. (1995) about the Saharan dust concentrations were confirmed at the CVAO at São Vicente during HV-filter sampling in the years 2007 and 2008.

Ionic constituents contribute with 43 to $65 \%$ to the mass. The aerosol bromide concentration $\left(1-8 \mathrm{ng} / \mathrm{m}^{3}\right)$ observed is

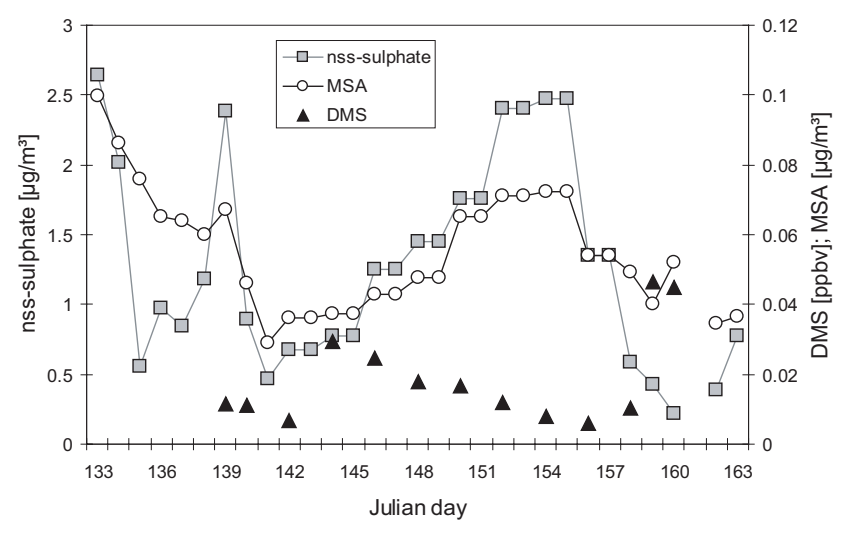

Fig. 7. Concentration of nss-sulphate and methanesulfonic acid (MSA) from filter samples and DMS mean mixing ratios (by courtesy of K. A. Read) during filter sampling intervals.

much lower than expected from sea salt, compared to magnesium and sodium concentration in PM. The water content of the filter samples was calculated between 27 and 48\%. OM and $\mathrm{EC}$ were generally found in low concentrations between 1.5 and $6 \%$ of the total mass.

The methanesulfonic acid concentration and the detected nss-sulphate indicate an active DMS chemistry above the tropical Atlantic (Fig. 7) where not only $\mathrm{OH}$ but also $\mathrm{Cl}$ appears to be involved, cf. Lawler et al. (2009). Results for MSA are in good agreement with the data reported by Allan et al. (2009) from the RRS Discovery during 25 and 26 May when the Discovery was close to Cape Verde. Kouvarakis and Mihalopoulos (2004) stated clearly that a point to correlation between MSA and DMS not exist while for MSA and nss-sulfate a direct correlation is reported by several authors (e.g., Saltzman et al. 1983, 1985; Ayers et al., 1986; Andreae et al., 1988; Bates et al., 1992; Allen et al., 1997).

The chemical mass closure for the HV-filter samples is hardly possible because the uncertainties of water content of filter samples and the mineral dust fraction which was not measured from filter samples.

\section{SMPS-APS measurements}

The physical PM characterization delivered number concentration size distribution with high time resolution. Characteristic daily variations were not observed for the number concentration as well as for the size distribution.

In Fig. 8, two particle number size distributions are shown. The first one (filled squares) was measured at 15 May within the last days of the dust event that occurred between 9 and 15 May. A typical bimodal distribution for marine air is seen for particles smaller than $0.5 \mu \mathrm{m}$ with the maxima at 0.045 and $0.2 \mu \mathrm{m}$. Particles of these modes mainly consist of nsssulfate, carbonaceous species and a few smaller sea salt particles. Also, a dominant mode with the maximum at $0.5 \mu \mathrm{m}$ 


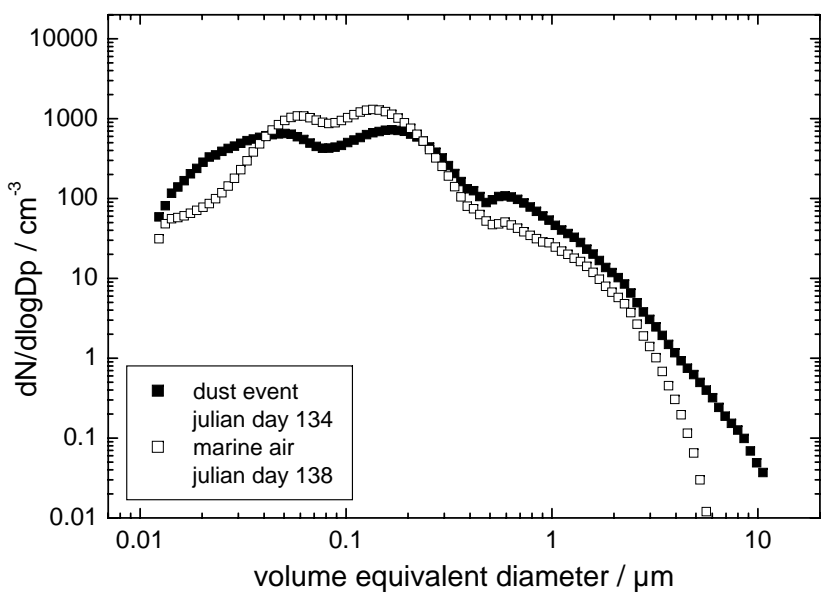

Fig. 8. Particle number size distributions measured at CVAO at 15 May (Julian day 134, influenced by Saharan dust) and 19 May (Julian day 138, marine air slightly polluted).

is visible for this first distribution including the dust particles from the Saharan desert. Particle diameters $>10 \mu \mathrm{m}$ were not measured but cannot be excluded.

The second distribution (open squares) was measured 4 days after the dust event and is mainly influenced by the oceanic emissions and secondary formed PM. In the submicron range until $0.5 \mu \mathrm{m}$ a difference to the first distribution was observed. The number concentration at 0.06 and $0.13 \mu \mathrm{m}$ was higher than during the dust event. For the second distribution, a third flat mode at $0.5 \mu \mathrm{m}$ is also visible but with a much lower number concentration and the largest particles are smaller than $6 \mu \mathrm{m}$.

\section{Comparison of techniques in use}

The differences between the HV-filter- and the impactormeasurements were observed previously and have different causes (Wieprecht et al., 2004). The inlet cutoff of the filter sampler, the higher adsorption of gaseous compounds and the higher water uptake by the quartz fiber filters are possible causes as well as the volatility of $\mathrm{NH}_{4} \mathrm{NO}_{3}$ and other semivolatile components in the low pressure impactor. In Fig. 9 the mass concentration differences between sampling systems are shown.

During this campaign, the inlet for the physical measurements was mounted just $4 \mathrm{~m}$ above ground, so that all measurements are influenced by the very strong sea spray that occurs close to the coast line. This is also the reason for the mass differences between chemical and physical measurements since the chemical measurements were conducted on top of the $30 \mathrm{~m}$ tower and were therefore hardly affected by the sea spray. The determination of masses from physical measurements was carried out with an aerosol density of $2.1 \mathrm{~g} / \mathrm{cm}^{3}$ which is an estimate for dry sea salt.

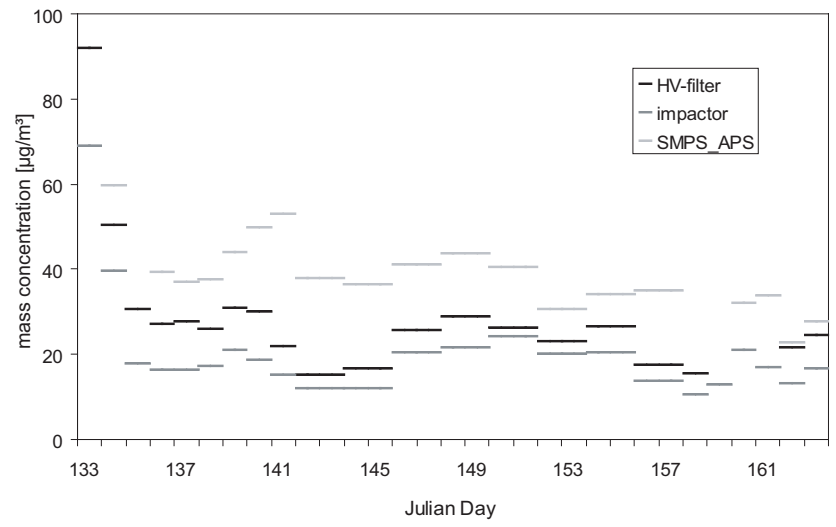

Fig. 9. Comparison of PM mass concentration measured by Digitel HV-filter sampler, five stage Berner low pressure impactor, and APS-SMPS combination.

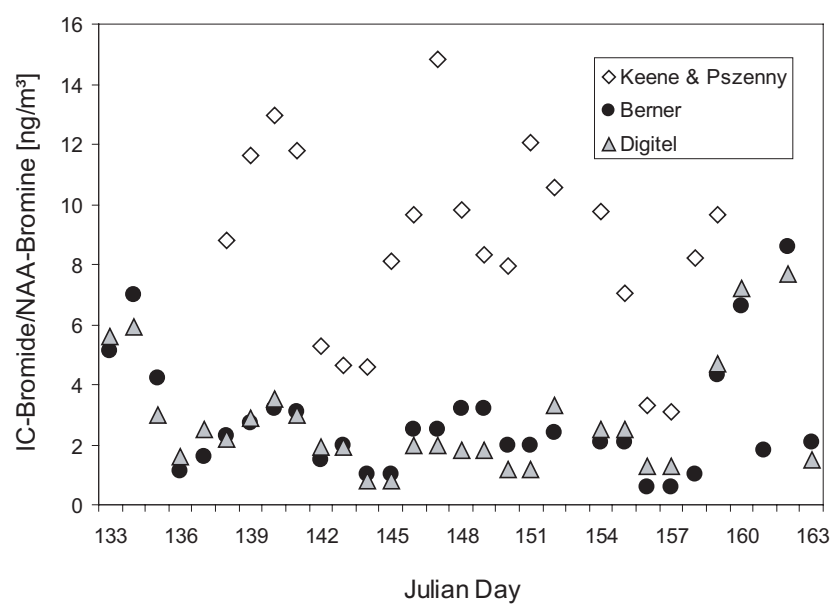

Fig. 10. Comparison of bromide concentrations measured in PM from Digitel HV-filters and Berner impactor samples (sum of all size fractions) with total bromine determination from NAA (by courtesy of A. A. P. Pszenny and W. C. Keene, personal communication, 2009).

\section{Halogen depletion}

The determination of the bromide and chloride depletion was performed according to Sander et al. (2003). As the calculation basis for sea water we have used the element ratios given by Sander et al. (2003) after Wilson (1975).

The $\mathrm{PM}_{10}$ bromide concentration was found much lower than expected from sea salt concentration. Bromide deficits in filter samples calculated to magnesium and sodium were observed to $88 \pm 6 \%$. In impactor measurements bromide depletions were calculated for the supermicron stages relative to magnesium to $82 \pm 12 \%$. According to this observation, intense chemical bromine activation must be the cause for the bromide loss in PM. The small difference between both methods can be explained by sampling losses from 
the filters. Pszenny and Keene (personal communication, 2009) measured total bromine by Neutron Activation Analysis (NAA) using a TSP sampler and found all the time 2-4 times higher bromine concentrations than our ion chromatographic method. Barrie et al. (1994) compared both methods and found a slightly lower concentration by IC analysis.

The discussion of bromide was concentrated on the filter samples and the two coarse mode fractions $(1.2-3.5 \mu \mathrm{m}$ and $3.5-10 \mu \mathrm{m}$ ) of the impactor knowing that the determination of bromide in lower impactor stages at concentrations in the range of the detection limit or below is not really possible. The difference between bromide concentrations measured in our samples and those of Pszenny and Keene is not understood at current when the differences in sampling systems, sample treatment and analytical methods are considered. The different sampling inlets PM10 and TSP can explain some of the differences and the non-ionic bromine compounds can contribute only insignificantly. The coarse mode $\mathrm{PM}\left(d_{p}>10 \mu \mathrm{m}\right)$ can contribute to less than $50 \%$ to total Bromide (cf. Fig. 31 in Keene et al., 2009). Our sampling time of 24 resp. $48 \mathrm{~h}$ according to $3 \mathrm{~h}$ from Pszenny and Keene may be a cause for higher bromide depletion from filters. Reactive gases like ozone (Barrie et al., 1994) and others may increase the bromide depletions found in our samples. The higher depletion in filter samples than in impactor samples agrees with this assumption because the better contact between streaming air and sampled PM than in impactors.

\section{Summary and conclusions}

Within the present study two different sampling systems for $\mathrm{PM}$ and physical characterization for number and size distribution were applied during the RHaMBLe intensive campaign. With the exception of the first two days where a Saharan dust event came to its end, mainly marine aerosols were measured at the CVAO. The mean mass concentration of the marine $\mathrm{PM}_{10}$ aerosol was about $24 \mu \mathrm{g} / \mathrm{m}^{3}$ at filters and $17 \mu \mathrm{g} / \mathrm{m}^{3}$ in impactor samples. Sea salt, water, long range transported dust and secondary aerosol components were found in varying proportion according to the PM size fraction. Minimal continental and anthropogenic influences have been observed by their EC content and mineral dust traces (iron and calcium) in air masses coming from southwestern Europe, the Canary Islands, North Africa, and North America. The size segregated chemical aerosol characterization has found at low absolute concentrations a high percentage of carbonaceous material in the Aitken mode particles decreasing with size increase. From the physical number size distribution, concentration peaks at 0.045 and $0.2 \mu \mathrm{m}$ indicate a weak anthropogenic influence during several days of marine air mass origin. Size fractions $0.14-0.42$ and $0.42-$ $1.2 \mu \mathrm{m}$ were dominated by secondary ionic material, long range transported dust and OC/EC. The coarse mode PM fractions are dominated by sea salt and water but during the first days by mineral dust. In the size-resolved impactor and the filter samples typical values of the chloride deficit were detected. In sub-micrometer PM the loss can reach 100\% decreasing with increasing particle size to $1 \%$. For bromide PM content, a high deficit of $82 \%$ from the coarse mode impactor fractions and of $88 \%$ was found from the PM10 filter samples. Both deficits for the particle phase halogenide ions point to an active halogen activation photochemistry. Finally, particle phase MSA highly correlated to nss-sulphate indicates an active DMS oxidation chemistry.

Acknowledgements. The IfT participation at the CVAO is supported by the German BMBF SOPRAN project (FKZ 03F0462J). Additional support through the EC project TENATSO (Project No. 37090) and the WGL SAW project TRACES is acknowledged. The authors do thank Bruno Faria and Luis Mendes for their substantial help at the CVAO on São Vicente. We thank William Keene and Alex Pszenny for helpful discussions and providing the NAA bromine data. Thanks also to Katie Read for the DMS data and her help at the CVAO. We acknowledge the laboratory work of Annelie Thomas, Eveline Neumann, Anett Dietze, and Brigitte Gerlach.

Edited by: G. McFiggans

\section{References}

Allan, J. D., Topping, D. O., Good, N., Irwin, M., Flynn, M., Williams, P. I., Coe, H., Baker, A. R., Martino, M., Niedermeier, N., Wiedensohler, A., Lehmann, S., Müller, K., Herrmann, H., and McFiggans, G.: Composition and properties of atmospheric particles in the eastern Atlantic and impacts on gas phase uptake rates, Atmos. Chem. Phys., 9, 9299-9314, 2009,

http://www.atmos-chem-phys.net/9/9299/2009/.

Allen, A. G., Dick, A. L., and Davison, B. M.: Sources of atmospheric methanesulphonate, non-sea-salt sulphate, nitrate and related species over the temperate South Pacific, Atmos. Environ., 31(2), 191-205, 1997.

Andreae, M. O., Berresheim, H., Andreae, T. W., Kritz, M. A., Bates, T. S., and Merrill, J. T.: Vertical-Distribution of Dimethylsulfide, Sulfur-Dioxide, Aerosol Ions, and Radon over the Northeast Pacific-Ocean, J. Atmos. Chem., 6(1-2), 149-173, 1988.

Ayers, G. P., Ivey, J. P., and Goodman, H. S.: Sulfate and Methanesulfonate in the maritime aerosol at Cape Grim, Tasmania, J. Atmos. Chem., 4 (1), 173-185, 1986.

Ayers, G. P., Gillett, R. W., Cainey, J. M., and Dick, A. L.: Chloride and bromide loss from sea-salt particles in southern ocean air, J. Atmos. Chem., 33, 299-319, 1999.

Baboukas, E. D., Kanakidou, M., and Mihalopoulos, N.: Carboxylic acids in gas and particulate phase above the Atlantic Ocean, J. Geophys. Res.-Atmos., 105(D11), 14459-14471, 2000.

Baker, A. R. and Jickells, T. D.: Mineral particle size as a control on aerosol iron solubility, Geophys. Res. Lett., 33, L17608, doi:10.1029/2006GL026557, 2006.

Barrie, L. A., Li, S.-M., Toom, D. L., Landsberger, S., and Sturges, W.: Lower tropospheric measurements of halogens, nitrates, and 
sulphur oxides during Polar Sunrise Experiment 1992, J. Geophys. Res., 99D, 25453-25467, 1994.

Bates, T. S., Calhoun, J. A., and Quinn, P. K.: Variations in the Methanesulfonate to Sulfate Molar Ratio in Submicrometer Marine Aerosol-Particles over the South-Pacific Ocean, J. Geophys. Res., 97 (D9), 9859-9865, 1992.

Birmili, W., Stratmann, F., and Wiedensohler, A.: Design of a DMA-based size spectrometer for a large particle size range and stable operation, J. Aer. Sci., 30, 549-553, 1999.

Bonnet, S. and Guieu, C.: Dissolution of atmospheric iron in seawater, Geophys. Res. Lett., 31(3), L03303, doi:10.1029/2003GL018423, 2004.

Charlson, R. J., Lovelock, J. E., Andreae, M. O., and Warren, S. G.: Oceanic phytoplankton, atmospheric sulphur, cloud albedo and climate, Nature, 326, 655-661, 1987.

Chen, Y. and Siefert, R. L.: Seasonal and spatial distribution s and dry deposition fluxes of atmospheric total and labile iron over the tropical and subtropical North Atlantic Ocean, J. Geophys. Res., 109, D09305, doi:10.1029/2003JD003958, 2004.

Chiapello, I., Bergametti, G., Gomes, L., Chatenet, B., Dulac, F., Pimenta, J., and Santos Suares, E.: An Additional Low Layer Transport of Sahelian and Saharan Dust over the North-Eastern Tropical Atlantic, Geophys. Res. Lett., 22, 3191-3194, 1995.

DeCarlo, P. F., Slowik, J. G., Warsnop, D. R., Davidovits, P., and Jimenez, J. L.: Particle morphology and density characterization by combined mobility and aerodynamic diameter measurements. Part 1: Theory, Aerosol Sci. Technol., 38, 1185-1205, 2004.

Duce, R. A., Wasson, J. T., Winchester, J. W., and Burns, E.: Atmospheric iodine, bromine, and chlorine, J. Geophys. Res., 68(13), 3943, 1963.

Gabriel, R., von Glasow, R., Sander, R., Andreae, M. O., and Crutzen, P. J.: Bromide content of sea-salt aerosol particles collected over the Indian Ocean during INDOEX 1999, J. Geophys. Res., 107(D19), 8032, doi:10.1029/2001JD001133, 2002.

Guieu, C., Loÿe-Pilot, M.-D., Ridame, C., and Thomas C.: Chemical characterization of the Saharan dust end-member: Some biogeochemical implications for the western Mediterranean Sea, J. Geophys. Res., 107(D15), 4258, doi:10.1029/2001JD000582, 2002.

Hand, J. L., Mahowald, N. M., Chen, Y., Siefert, R. L., Luo, C., Subramaniam, A., and Fung, I.: Estimates of atmosphericprocessed soluble iron from observations and a global mineral aerosol model: Biogeochemical implications, J. Geophys.Res., 109(D17), D17205, doi:10.1029/2004JD004574, 2004.

Herrmann, H.: Kinetics of aqueous phase reactions relevant for atmospheric chemistry, Chem. Rev., 103, 4691-4716, 2003.

Herrmann, H., Brüggemann, E., Franck, U., Gnauk, T., Löschau, G., Müller, K., Plewka, A., and Spindler, G.: A source study of PM in Saxony by size-segregated characterization, J. Atmos. Chem., 55, 103-130, 2006.

Hsieh, L. Y., Kuo, S. C., Chen, C. L., and Tsai, Y. I.: Origin of lowmolecular-weight dicarboxylic acids and their concentration and size distribution variation in suburban aerosol, Atmos. Environ., 41 (31), 6648-6661, 2007.

Hsieh, L. Y., Kuo, S. C., Chen, C. L., and Tsai, Y. I.: Size distributions of nano/micron dicarboxylic acids and inorganic ions in suburban PM episode and non-episodic aerosol, Atmos. Environ., 43(29), 4396-4406, 2009.

Johansen, A. M., Siefert, R. L., and Hoffmann, M. R.: Chemical composition of aerosol collected over the tropical North Atlantic Ocean, J. Geophys. Res., 105, 15277-15312, 2000.

Keene, W. C., Pszenny, A. A. P., Jacob, D. J., Duce, R. A., Galloway, J. N., Schultz-Tokos, J. J., Sievering, H., and Boatman, J. F.: The geochemical cycling of reactive chlorine through the marine troposphere, Global Biogeochem. Cy., 4, 407-430, 1990.

Keene, W. C., Pszenny, A. A. P., Maben, J. R., and Sander, R.: Variation of marine aerosol acidity with particle size, Geophys. Res. Lett., 29(7), 1101, doi:10.1029/2001GL013881, 2002.

Keene, W. C., Pszenny, A. A. P., Maben, J. R., Stevenson, E., and Wall, A.: Closure evaluation of size-resolved aerosol $\mathrm{pH}$ in the New England coastal atmosphere during summer, J. Geophys. Res., 109, D23307, doi:10.1029/2004JD004801, 2004.

Keene, W. C., Long, M. S., Pszenny, A. A. P., Sander, R., Maben, J. R., Wall, A. J., O’Halloran, T. L., Kerkweg, A., Fischer, E. V., Schrems, O.: Latitudinal variation in the multiphase chemical processing of inorganic halogens and related species over the eastern North and South Atlantic ocean, Atmos. Chem. Phys., 9, 7361-7385, 2009, http://www.atmos-chem-phys.net/9/7361/2009/.

Kettle, A. J. and Andreae, M. O.: Flux of dimethylsulfide from the oceans: a comparison of updated data sets and flux models, J. Geophys. Res., 105, 26793-26808, 2000.

Kouvarakis, G. and Mihalopoulos, N.: Seasonal variation of dimethylsulfide in the gas phase and of methanesulfonate and non-sea-salt sulfate in the aerosols phase in the Eastern Mediterranean atmosphere, Atmos. Environ., 36 (6), 929-938, 2002.

Lafon, S., Rajot, J. L., Alfaro, S. C., and Gaudichet, A.: Quantification of iron oxides in desert aerosol, Atmos. Environ., 38(8), 1211-1218, 2004.

Lawler, M. J., Finley, B. D., Keene, W. C., Pszenny, A. A. P., Read, K. A., von Glasow, R., and Saltzmann, E. S.: Pollutionenhanced reactive chlorine chemistry in the eastern tropical Atlantic boundary layer, Geophys. Res. Lett., 36, L08810, doi:10.1029/2008GL036666, 2009.

Lee, J. D., McFiggans, G., Allan, J. D., Carpenter, L. J., Jones, C. E., Lewis, A. C., Moller, S. J., Read, K. A., Methven, J., Fuentes, E., Good, N., Irwin, M., Commane, R., Furneuax, K. L., Goddard, A., Ingham, T., Whalley, L. K., Heard, D. E., Mahajan, A., Oetjen, H., Plane, J. M. C., Saiz-Lopez, A., Hollingworth, A., Ball, S. M., Benton, A., Jones, R., Baker, A. R., O`Doherty, S., Young, D., Müller, K., Lehmann, S., Niedermeier, N., Müller, T., Herrmann, H., Wiedensohler, A., Pszenny, A. A. P., Kenne, W. C., Long, M. S., Sander, R., Lawler, M. J., Saltzman, E. S., and Finley, B. D.: Reactive halogens in the marine boundary layer (RHaMBLe): context of the tropical North Atlantic Ocean experiments, Atmos. Chem. Phys., 10, 1031-1055, 2010,

http://www.atmos-chem-phys.net/10/1031/2010/.

Mahowald, N. M., Baker A. R., Bergametti, G., Brooks, N., Duce, R. A., Jickells, T. D., Kubilay, N., Prospero, J. M., and Tegen, I.: Atmospheric global dust cycle and iron inputs to the ocean, Global Biogeochem. Cy., 19, GB4025, doi:10.1029/2004GB002402, 2005.

Mochida, M., Umemoto, N., Kawamura, K., and Uematsu, M.: Bimodal size distribution of $\mathrm{C}_{2}-\mathrm{C}_{4}$ dicarboxylic acids in the marine aerosols, Geophys. Res. Lett., 30(13), 1672, doi:10.1029/2003GL017451, 2003.

Moreno, T., Querol, X., Castillo, S., Alastuey, A., Cuevas, E., Herrmann, L., Mounkaila, M., Elvira, J., and Gibbons, W.: Geo- 
chemical variations in aeolian mineral particles from the SaharaSahel Dust Corridor, Chemosphere, 65, 261-270, 2006.

Müller, C., Iinuma, Y., Karstensen, J., van Pinxteren, D., Lehmann, S., Gnauk, T., and Herrmann, H.: Seasonal variation of aliphatic amines in marine sub-micrometer particles at the Cape Verde islands, Atmos. Chem. Phys., 9, 9587-9597, 2009,

http://www.atmos-chem-phys.net/9/9587/2009/.

Neusüß, C., Weise, D., Birmili, W., Wex, H., Wiedensohler, A., and Covert, D. S.: Size-segregated chemical, gravimetric and number distribution-derived mass closure of the aerosol in Sagres, Portugal during ACE-2. Tellus (B), 52, 169-184, 2000.

Neusüß, C., Gnauk, T., Plewka, A., Herrmann, H., and Quinn, P. K., Carbonaceous aerosol over the Indian Ocean: OC/EC fractions and selected specifications from sizesegregated onboard samples, J. Geophys. Res., 107(D19), 8031, doi:10.1029/2001JD000327, 2002.

Prospero, J. M. and Carlson, T. N.: Saharan Air Outbreaks over the Tropical North-Atlantic, Pure Appl. Geophys., 119, 677-691, 1981.

Read, K. A., Mahajan, A. S., Carpenter, L. J., Evans, M. J., Faria, B. V. E., Heard, D. E., Hopkins, J. R., Lee, J. D., Moller, S. J., Lewis, A. C., Mendes, L., McQuaid, J. B., Oetjen, H., SaizLopez, A., Pilling, M. J., and Plane, J. M. C.: Extensive halogenmediated ozone destruction over the tropical Atlantic Ocean, Nature, 453, 1232-1235, doi:10.1038/nature07035, 2008.

Rijkenberg, M. J. A., Powell, C. F., Dall'Osto, M., Nielsdottir, M. C., Patey, M. D., Hill, P. G., Baker, A. R., Jickells, T. D., Harrison, R. M., and Achterberg, E. P.: Changes in iron speciation following a Saharan dust event in the tropical North Atlantic Ocean, Mar. Chem., 110, 56-67, 2008.

Saltzman, E. S., Savoie, D. L., Zika, R. G., and Prospero, J. M.: Methane Sulfonic-Acid in the marine atmosphere, J. Geophys. Res., 88(15), 897-902, 1983.

Saltzman, E. S., Savoie, D. L., Prospero, J. M., and Zika, R. G.: Atmospheric Methane Sulfonic-Acid and Non-Sea-Salt Sulfate at Fanning and American Samoa, Geophys. Res. Lett., 12(7), 437440, 1985.

Sander, R., Keene, W. C., Pszenny, A. A. P., Arimoto, R., Ayers, G. P., Baboukas, E., Cainey, J. M., Crutzen, P. J., Duce, R. A., Honninger, G., Huebert, B. J., Maenhaut, W., Mihalopoulos, N., Turekian, V. C., and Van Dingenen, R.: Inorganic bromine in the marine boundary layer: a critical review, Atmos. Chem. Phys., 3, 1301-1336, 2003,

http://www.atmos-chem-phys.net/3/1301/2003/.

Schepanski, K., Tegen, I., and Macke, A.: Saharan dust transport and deposition towards the tropical northern Atlantic, Atmos. Chem. Phys., 9, 1173-1189, 2009,

http://www.atmos-chem-phys.net/9/1173/2009/.
Schmid, H., Laskus, L., Abraham, H.J., Baltensperger, U., Lavanchy, V., Bizjak, M., Burba, P., Cachier, H., Crow, D., Chow, J., Gnauk, T., Even, A., ten Brink, H. M., Giesen, K. P., Hitzenberger, R., Hueglin, C., Maenhaut, W., Pio, C., Carvalho, A., Putaud, J. P., Toom-Sauntry, D., and Puxbaum, H.: Results of the "carbon conference" international aerosol carbon round robin test stage I, Atmos. Environ., 35 (12), 2111-2121, 2001.

Schroth, A. W., Crusius, J., Sholkowitz, E. R., and Bostick, B. C.: Iron solubility driven by speciation in dust sources to the ocean, Nature Geosci., 2, 337-340, 2009.

ten Brink, H. W., Maenhaut, W., Hitzenberger, R., Gnauk, T., Spindler, G., Even, A., Chi, X. G., Bauer, H., Puxbaum, H., Putaud, J. P., Tursic, J., and Berner, A.: INTERCOMP2000: the comparability of methods in use in Europe for measuring the carbon content of aerosol, Atmos. Environ., 38, 6507-6519, 2004.

Turpin, B. J., Saxena, P., and Andrews, E.: Measuring and simulating particulate organics in the atmosphere: problems and prospects, Atmos. Environ., 34, 2983-3013, 2000.

Vogt, R., Crutzen, P. J., and Sander, R.: A mechanism for halogen release from sea-salt aerosol in the remote marine boundary layer, Nature, 383(6598), 327-330, 1996.

von Glasow, R., Sander, R., Bott, A., and Crutzen, P. J.: Modeling halogen chemistry in the marine boundary layer. 1.Cloud-free MBL, J. Geophys. Res., 107, 4341, doi:10.1029/2001JD000942, 2002 a.

von Glasow, R., Sander, R., Bott, A., Crutzen, P. J.: Modeling halogen chemistry in the marine boundary layer. 2 . Interactions with sulphur and cloud-covered MBL, J. Geophys. Res., 107, 4341, doi:10.1029/2001JD000943, 2002b.

Wieprecht, W., Acker, K., Müller, K., Spindler, G., Brüggemann, E., Maenhaut, W. Chi, X., Hitzenberger, R., Bauer, H., and ten Brink, H. M.: INTERCOMP2000: Ionic constitution and comparison of filter and impactor, Atmos. Environ., 38, 6477-6486, 2004.

Wilson, T. R. S.: Salinity and the major elements of sea water, in: Chemical Oceanography, Vol. 1, 2nd Ed., edited by: Riley, J. P. and Skirrow, G., Academic Press, 365-413, 1975.

Yang, H. and Yu, J. Z.: Uncertainties in charring correction in the analysis of elemental and organic carbon in atmospheric aerosol particles by thermal/optical methods, Environ Sci. Technol., 36, 5199-5204, 2002. 